\title{
Efficiency of Palestinian International Arbitration Chamber
}

\author{
Hussein Abu Zant \\ Civil Engineering Department \\ An-Najah National University, PO. Box 7 Nablus, Palestine.
}

\begin{abstract}
Arbitration is a private system to resolve disputes between parties that involves a final and binding award. Arbitration nowadays is more preferable than court since the parties choose the experts arbitrators, and arbitration has a shorter process than in court. The Palestinian International Arbitration Chamber (PIAC) was established in Palestine by Italian efforts and others. The efficiency of PIAC being determined in this paper through the questionnaire that distributed among the contractors to measure their responds. The data collected were analyzed using (SPSS-17) to provide answers to the questions of the study. To achieve the objectives of the study, the researcher used a 43-items questionnaire for construction companies' sample. The questionnaire consisted of four sections; the first focused on demographic data of the respondents such company classification according to the Palestinian Contractors' Union, age, capital and field of work. The second section consisted of three parts about the contractor's knowledge about the chamber of arbitration, the activities that chamber carries out for reducing or banning disputes between the contractor and the owner, and practices and policies which the chamber carries out. The third section focused on the performance of the chamber in solving problems between the contractor and the owner. Finally, the last section focused on the obstacles that face the chamber and the procedures of treatment of these obstacles. The results of analyzing of questionnaire create reasonable suggestions to be handled by PIAC in order to improve its role and to be more efficient.
\end{abstract}

The analysis of questionnaire shows that (PIAC) must enhance the awareness of contractors and owners about the importance of chamber in solving disputes between contractors and owners. Besides, (PIAC) should adopt qualified arbitrators to spend their efforts to solve disputes between contractors and owners. In addition, (PIAC) should continue its policy to solve disputes in a secrete manner. A lot of remedial actions must be adopted by (PIAC) regarding to the analysis of questionnaire created by researcher.

Keywords: Agreements; arbitration, contracts, dispute, international agreements.

\section{INTRODUCTION}

Since Palestine is a developing country, there are several projects and transactions. These projects and transactions involve the parties; each of them hopes to achieve his aspiration. Therefore, potential conflicts may arise caused disputes between these parties. One of the methods that resolve these disputes is arbitration. Arbitration is a private procedure to solve disputes between dispute parties without judicial system. Arbitration in general is more beneficial for all parties of disputes, arbitration will save time, cost, and gives an ability to resolve international conflicts.

In the process of arbitration, there are several conditions that assist the recent growth of arbitration in Palestine; such as legal infrastructure in the form of modern legislation governing arbitration procedure and court proceedings, arbitration clauses in contracts, existing of arbitration institutions.

The Palestinian International Arbitration Chamber (PIAC) was founded by a project promoted by the Italian Cooperation, the Umbria Region with a scientific support of the University of Perugia, and partnership of several important Palestinian National Organizations and association. This project aims to create qualified professionals of human resources in this chamber. PIAC is an independent entity with financial and administrative autonomy and legal personality. PIAC has no political purposes, religion or nationality, nor pursues any activity in this direction. The official language is Arabic, and also Italian, English and French [1].

In the "Practitioner's Guide to Arbitration in the Middle East and North Africa, is a comprehensive guide to arbitration in Arab countries. Many of these countries are undertaking great legislative efforts to send a message to the international community to enhance and support international trade.

\section{QUESTIONNAIRE}

The questionnaire was made and distributed over many contractors in order to answer the related questions to form conceptual idea about the efficiency of PIAC.

This research paper deals with the effectiveness of the Palestinian International Arbitration chamber (PIAC), in where the Italians supported this chamber, and several 
bulletins were issued and this chamber seeks to resolve disputes between conflicting parties.

In this research, the researcher focuses on trying to find solutions to the dispute between the contractor and the owner or consultant who represents the owner. It is worth mentioning that the chamber has many positives, especially the ability of PIAC to keep the procedure and the resulting award confidential. Besides, the neutrality and the likelihood of obtaining enforcement internationally. Also, PIAC has the factor of 'quick speed' in which it can resolve the dispute in less time that the time the court needs to do so. The arbitrators will have also full experts to make the final decisions between arbitrators. Therefore; researcher was studying the effectiveness of the Palestinian International Arbitration Chamber in the resolution of the dispute between the contractor the owner and work procedures that will reduce the disputes between the contractor and the owner.

\section{ANALYSIS OF QUESTIONNAIRE}

The sample consisted of 30 companies in different sectors in Palestine. The background of the study sample is varied in terms of company classification, age, capital and field of work.

\section{Instrumentation}

To achieve the objectives of the study, the researchers used a 46-item questionnaire for construction companies sample by using previous literature and the researcher's own experience in the field of Engineering. The questionnaire consisted of four sections; the first focused on demographic data of the respondents such company classification according to the Palestinian Contractors' Union, age, capital and field of work. The second section consisted of three parts about the contractor's knowledge about the chamber of arbitration, the activities that chamber carries out for reducing or banning disputes between the contractor and the owner, and practices and policies which the chamber carries out. The third section is about the affect the success or failure in the performance of the chamber in solving problems between the contractor and the owner. Finally, the fourth section is about treatments of the difficulties facing Arbitration Chamber.

The scores of responses to each item were calculated according to a five-point Likert scale for the first three domains responses in which strongly agree $=5$ points, agree $=4$ points, neutral $=3$, disagree $=2$ points and strongly disagree $=1$ point.

\section{Validity of the Questionnaire}

To ensure the validity of the questionnaire, it was rated by a jury of experts in the field of engineering at An-Najah National University. The respondents' comments and the jury's suggestions were taken into consideration to modify and improve the questionnaire's content and wordings by omitting, adding or rephrasing items bringing the number of items remained 46 items.

\section{Reliability of the Questionnaire}

The reliability of the questionnaire as calculated through Cronbach Alpha formula for the total degree was (0.953) which is acceptable for conducting the research.

\section{Procedure}

The final draft of the questionnaire was given to company owners at West Bank. It took about five weeks for the instrument to be distributed, collected, and returned to the researchers. The total number of the returned questionnaires was 30. No questionnaire has been excluded as their responses were neither consistent nor complete.

\section{Data Analysis}

The data collected were analyzed using (SPSS-17) to provide answers to the questions of the study. Means, frequencies, standard deviations two independent sample T-test and One Way ANOVA test. To analyze the findings, the researchers used the following scales to represent the estimation level of sample responses:

\begin{tabular}{|lll|}
\hline 4.20 and more & $-\mathbf{8 4 . 0} \%$ and more & Very High \\
$3.40-4.19$ & $-68.0-83.8 \%$ & High \\
$2.60-3.39$ & $-52.0-67.8 \%$ & Moderate \\
1-80- 2.59 & $-36.0-51.8 \%$ & Low \\
Less than 1.8 & $-35.9 \%$ and less & Very Low \\
\hline
\end{tabular}

\section{RESULTS BASED ON SPSS ANALYSIS}

This study aimed at identifying the effectiveness of the International Palestinian Chamber of arbitration in reducing and banning disputes between contractors and project owner. It also aimed at identifying the effect of several variables on the responses. To accomplish the aims of the study, the researcher analyzed the data in accordance with the study questions and the results were as follows:

\section{Results related to Study Questions}

Results related to the First Question. What is the degree of the effectiveness of the International Palestinian Chamber of arbitration in reducing and banning disputes between contractors and project owner?

To answer this question, the researcher used means and standard deviations and estimation level as shown in following tables. 
International Journal of Engineering Research and Technology. ISSN 0974-3154, Volume 13, Number 9 (2020), pp. 2444-2452

(C) International Research Publication House. https://dx.doi.org/10.37624/IJERT/13.9.2020.2444-2452

Table (2) Means, Standard Deviations and estimated level of the effectiveness of the International Palestinian Chamber of arbitration in reducing and banning disputes between contractors and project owner for the study domains and the total degree in descending order according to the mean.

\begin{tabular}{|r|r|l|r|r|r|r|}
\hline & & & & & & \\
\hline
\end{tabular}

Table (2) shows that the total degree of the effectiveness of the International Palestinian Chamber of arbitration in reducing and banning disputes between contractors and project owner for the total degree was (67.6) which suggests Moderate level of estimation. The highest mean was given to the domain (The effectiveness of chamber of arbitration activities in solving disputes between the contractor and the project owner). The lowest was for the domain (Contractor's and owner's knowledge about the chamber of arbitration).

The following tables show the results details:

Table (3): Means, Standard Deviations and estimated level of Means, Standard Deviations and estimated level of the effectiveness of the International Palestinian Chamber of arbitration in reducing and banning disputes between contractors and project owner for the first domain (Contractor's and owner's knowledge about the chamber of arbitration) in descending order according to the mean

\begin{tabular}{|c|c|c|c|c|c|c|c|}
\hline$\dot{\mathbf{Z}}$ & 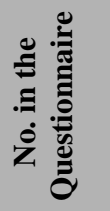 & $\stackrel{\Xi}{\Xi}$ & $\stackrel{\mathscr{E}}{\stackrel{\Xi}{ٍ}}$ & 를 & 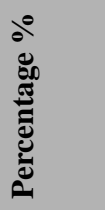 & : & 巳一 \\
\hline 9. & 13 & $\begin{array}{l}\text { The chamber employs a cadre career who would choose the skillful } \\
\text { people from a list of arbitrators to resolve disputes between the } \\
\text { contractor and the owner. }\end{array}$ & 3.60 & 0.89 & 72.0 & & High \\
\hline 10 & 12 & $\begin{array}{l}\text { The chamber employs a crew who can choose list of skillful } \\
\text { arbitrators to solve disputes between the contractor and the project } \\
\text { owner }\end{array}$ & 3.56 & 1.25 & 71.2 & & High \\
\hline 11 & 15 & $\begin{array}{l}\text { List of arbitrators adopts transparency in order to inform the dispute } \\
\text { parties about the results }\end{array}$ & 3.53 & 1.00 & 70.6 & & High \\
\hline 12 & 14 & The chamber solve dispute in a reasonable time without wasting it & 3.43 & 1.04 & 68.3 & & High \\
\hline 13 & 9 & $\begin{array}{l}\text { The chamber employs a cadre career who would choose the skillful } \\
\text { people from a list of arbitrators to resolve disputes between the } \\
\text { contractor and the owner. }\end{array}$ & 3.20 & 1.34 & 64.0 & & Moderate \\
\hline 14 & 11 & $\begin{array}{l}\text { The chamber conducts special workshops for contractors to identify } \\
\text { responsibilities and duties for both contractor and owner }\end{array}$ & 3.16 & 1.39 & 64.0 & & Moderate \\
\hline 15 & 10 & $\begin{array}{l}\text { The chamber conducts sustainable studies of the construction } \\
\text { contracts between the contractor and the owner }\end{array}$ & 3.00 & 1.20 & 60.0 & & Moderate \\
\hline \multicolumn{3}{|r|}{ Total } & 3.35 & 0.94 & 67.0 & & Moderate \\
\hline
\end{tabular}


International Journal of Engineering Research and Technology. ISSN 0974-3154, Volume 13, Number 9 (2020), pp. 2444-2452

(C) International Research Publication House. https://dx.doi.org/10.37624/IJERT/13.9.2020.2444-2452

Table (3) shows that the total degree of the effectiveness of the International Palestinian Chamber of arbitration in reducing and banning disputes between contractors and project owner for the first domain (Contractor's and owner's knowledge about the chamber of arbitration) was (63.4) which suggest moderate level of estimation. The highest mean was given to the item (There is knowledge among the contractors about the International Palestinian Chamber of Arbitration.). The lowest was for the item (There is knowledge among the contractors about the chamber date of establishment).

Table (4): Means, Standard Deviations and estimated level of Means, Standard Deviations and estimated level of the effectiveness of the International Palestinian Chamber of arbitration in reducing and banning disputes between contractors and project owner for the second domain (The effectiveness of chamber of arbitration activities in reducing disputes) in descending order according to the mean.

\begin{tabular}{|c|c|c|c|c|c|c|}
\hline$\stackrel{\dot{Z}}{\mathbf{Z}}$ & 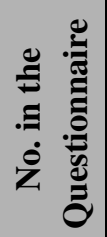 & $\underset{\Xi}{\Xi}$ & 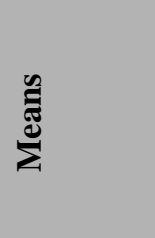 & 를 & 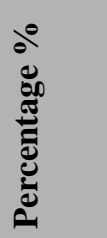 & 㟒 \\
\hline 1. & 1 & $\begin{array}{l}\text { There is knowledge among the contractors about the } \\
\text { International Palestinian Chamber of Arbitration }\end{array}$ & 3.83 & 0.98 & 76.6 & High \\
\hline 2. & 4 & $\begin{array}{l}\text { There is a clear knowledge among the contractors about the } \\
\text { website of the International Palestinian Chamber of } \\
\text { Arbitration }\end{array}$ & 3.23 & 1.19 & 64.6 & Moderate \\
\hline 3. & 3 & $\begin{array}{l}\text { There is a direct connection between the Chamber and the } \\
\text { contractor }\end{array}$ & 3.23 & 1.19 & 64.6 & Moderate \\
\hline 4. & 6 & $\begin{array}{l}\text { There is a clear knowledge among the contractors about the } \\
\text { location of the International Palestinian Chamber of } \\
\text { Arbitration }\end{array}$ & 3.16 & 1.20 & 63.2 & Moderate \\
\hline 5. & 2 & $\begin{array}{l}\text { There is a knowledge among the contractors about the } \\
\text { arbitrators list }\end{array}$ & 3.10 & 1.26 & 62.0 & Moderate \\
\hline 6. & 5 & $\begin{array}{l}\text { There is a knowledge among the contractors about the } \\
\text { chamber activities }\end{array}$ & 3.00 & 1.174 & 60.0 & Moderate \\
\hline 7. & 7 & $\begin{array}{l}\text { There is a knowledge among the contractors about the } \\
\text { head and employees of the chamber }\end{array}$ & 2.93 & 1.20 & 58.6 & Moderate \\
\hline 8. & 8 & $\begin{array}{l}\text { There is a knowledge among the contractors about the } \\
\text { chamber date of establishment }\end{array}$ & 2.86 & 1.19 & 57.2 & Moderate \\
\hline \multicolumn{3}{|r|}{ Total } & 3.17 & 1.02 & 63.4 & Moderate \\
\hline
\end{tabular}

Table (4) shows that the total degree of the effectiveness of the International Palestinian Chamber of arbitration in reducing and banning disputes between contractors and project owner for the second domain (The effectiveness of chamber of arbitration activities in reducing disputes) was (67.0) which suggest moderate level of estimation. The highest mean was given to the item (The chamber employs a crew who can choose list of skillful arbitrators to solve disputes between the contractor and the project owner.). The lowest was for the item (The chamber conducts sustainable studies of the construction contracts between the contractor and the owner). 
International Journal of Engineering Research and Technology. ISSN 0974-3154, Volume 13, Number 9 (2020), pp. 2444-2452

(C) International Research Publication House. https://dx.doi.org/10.37624/IJERT/13.9.2020.2444-2452

Table (5): Means, Standard Deviations and estimated level of Means, Standard Deviations and estimated level of the effectiveness of the International Palestinian Chamber of arbitration in reducing and banning disputes between contractors and project owner for the third domain (The effectiveness of chamber of arbitration policies and procedures in solving disputes between the contractor and the project owner.) in descending order according to the mean.

\begin{tabular}{|c|c|c|c|c|c|c|}
\hline$\dot{\mathbf{z}}$ & 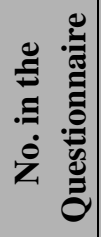 & $\stackrel{\Xi}{\rightleftarrows}$ & 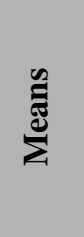 & 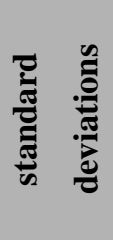 & 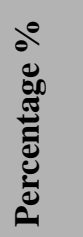 & 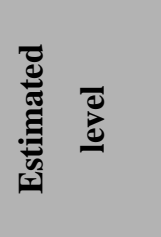 \\
\hline 16. & 23 & The chamber works in full secret for solving disputes & 4.06 & 0.90 & 81.2 & High \\
\hline 17. & 16 & The chamber follows the legal procedures in solving disputes & 3.80 & 0.88 & 76.0 & High \\
\hline 18. & 17 & $\begin{array}{l}\text { The chamber takes decisions after listening to all disputed } \\
\text { parties }\end{array}$ & 3.76 & 0.93 & 73.2 & High \\
\hline 19. & 18 & $\begin{array}{l}\text { There is contentment among both the contractors and the owner } \\
\text { that the chamber has adequate knowledge about solving dispute. }\end{array}$ & 3.63 & 1.03 & 72.6 & High \\
\hline 20. & 19 & $\begin{array}{l}\text { The chamber has experienced crew of employees who are } \\
\text { qualified in solving dispute }\end{array}$ & 3.46 & 1.07 & 69.2 & High \\
\hline 21. & 22 & The chamber consumes long time in solving disputes & 3.40 & 1.10 & 68.0 & High \\
\hline 22. & 21 & $\begin{array}{l}\text { The chamber works in way which encourages investment in } \\
\text { Palestine }\end{array}$ & 3.40 & 1.03 & 68.0 & High \\
\hline 23. & 20 & $\begin{array}{l}\text { The chamber demands high amount of money for solving } \\
\text { disputes between the contractor and the owner }\end{array}$ & 3.36 & 1.06 & 67.2 & Moderate \\
\hline & & Total & 3.61 & 0.75 & 72.2 & High \\
\hline
\end{tabular}

Statistical evidence of Table (5) shows that the total degree of the effectiveness of the International Palestinian Chamber of arbitration in reducing and banning disputes between contractors and project owner for the third domain (The effectiveness of chamber of arbitration activities in solving disputes between the contractor and the project owner) was (72.2) which suggest high level of estimation. The highest mean was given to the item (The chamber works in full secret for solving disputes). The lowest was for the item (The chamber demands high amount of money for solving disputes between the contractor and the owner).

Results related to the Third Question. What is the degree of the effects of difficulties on the chamber of arbitration success or fail?

To answer this question, the researcher used means, standard deviations, percentages and estimation.

The results are shown in following table. 
International Journal of Engineering Research and Technology. ISSN 0974-3154, Volume 13, Number 9 (2020), pp. 2444-2452

(C) International Research Publication House. https://dx.doi.org/10.37624/IJERT/13.9.2020.2444-2452

Table (6): Means, Standard Deviations and estimated level of Means, Standard Deviations, percentages and estimated level of the effects of difficulties on the chamber of arbitration success or fail in descending order according to the mean.

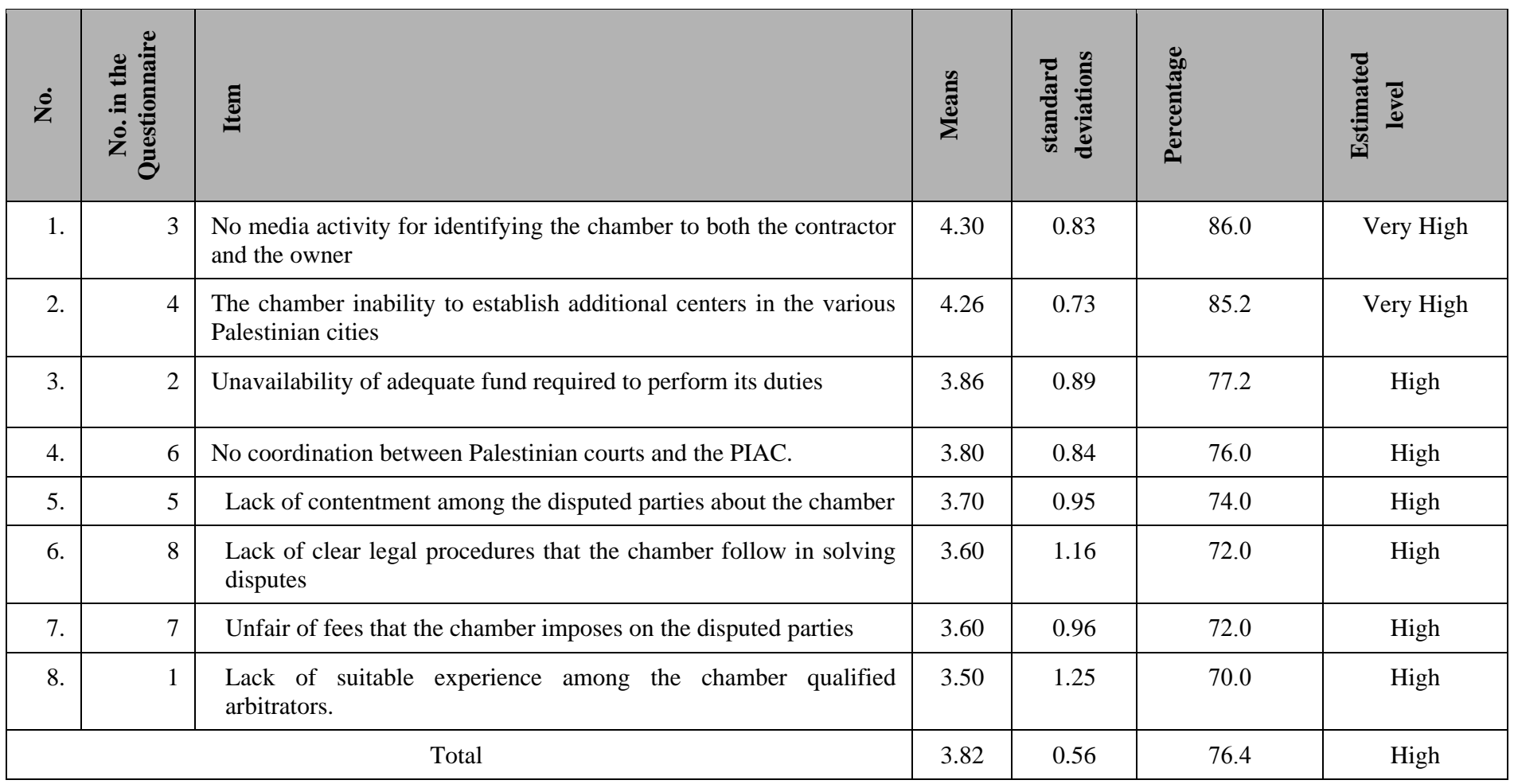

Table (6) shows that the total degree of the effects of difficulties on the chamber of arbitration success or fail was (76.4) which suggest high level of estimation. The highest mean was given to the item (No media activity for identifying the chamber to both the contractor and the owner. The lowest was for the item (Lack of suitable experience among the chamber employees.).

\section{Results related to the Fourth Question.}

What is the degree of the importance of procedures adopted in solving obstacles that face the chamber of arbitration?

To answer this question, the researchers used means, standard deviations, percentages and estimation.

The results are shown in following table.

Table (7): Means, Standard Deviations and estimated level of Means, Standard Deviations, percentages and estimated level of solutions of difficulties on the chamber of arbitration success or fail in descending order according to the mean.

\begin{tabular}{|r|r|l|c|c|c|c|}
\hline & 3 & $\begin{array}{l}\text { Providing media resources which have experiences in } \\
\text { identifying the need for chamber for both the contractor and the } \\
\text { project owner }\end{array}$ & 4.56 & 0.56 & 91.2 & Very High \\
\hline 1. & 1 & $\begin{array}{l}\text { Providing list of qualified arbitrators who have experiences in } \\
\text { solving disputes }\end{array}$ & 4.56 & 0.67 & 91.2 & Very High \\
\hline 3. & 5 & $\begin{array}{l}\text { Providing awareness bulletins and brochures clarifying the } \\
\text { chamber activities in solving previous disputes }\end{array}$ & 4.50 & 0.62 & 90.0 & Very High \\
\hline 4. & 8 & $\begin{array}{l}\text { Providing specialists who can evaluate and estimate the chamber } \\
\text { performances by periodical meetings }\end{array}$ & 4.50 & 0.82 & 90.0 & Very High \\
\hline 5. & 4 & \begin{tabular}{l} 
Establishing centers in the main Palestinian cities \\
\hline
\end{tabular} & 4.33 & 0.88 & 86.6 & Very High \\
\hline
\end{tabular}


International Journal of Engineering Research and Technology. ISSN 0974-3154, Volume 13, Number 9 (2020), pp. 2444-2452

(C) International Research Publication House. https://dx.doi.org/10.37624/IJERT/13.9.2020.2444-2452

\begin{tabular}{|r|r|l|c|c|c|c|}
\hline 6. & 2 & $\begin{array}{l}\text { Providing financial resources in order to support the chamber } \\
\text { work }\end{array}$ & 4.30 & 0.74 & 86.0 & Very High \\
\hline 7. & 6 & $\begin{array}{l}\text { Finding cooperation and coordination between Palestinian } \\
\text { courts and the chamber in order to execute the courts } \\
\text { resolutions about solving disputes }\end{array}$ & 4.26 & 0.90 & 85.2 & Very High \\
\hline 8. & 7 & Defining fair clear fees for solving disputes & 4.20 & 0.76 & 84.0 & 88.0 \\
\hline Total & 4.40 & 0.50 & Very High High \\
\hline
\end{tabular}

Table (7) shows that the total degree of the effects of the importance of procedures adopted in solving obstacles that face the chamber of arbitration were (88.0) which suggest a very high level of estimation. The highest mean was given to the item (Providing media resources which have experiences in identifying the need for chamber for both the contractor and the project owner) The lowest was for the item (Defining fair clear fees for solving disputes.).

\section{RESULTS BASED ON SPSS ANALYSIS}

As a result, based on the analysis of Table 2, almost all contractors agree that the importance role of Palestinian International Arbitration Chamber (PIAC) summarized and represented in solving disputes between contractors and owners, and the main point resulted from the analysis of questionnaire is the policies rules and procedure of PIAC, this item is mentioned in the third part in section 2 of questionnaire.

In general, there is a clear lack in the contractor's knowledge about Palestinian International arbitration chamber (PIAC), contractors believe in the necessity of the existence of PIAC to resolve disputes although the newly constructed chamber in addition to the lack of knowledge of the chamber between contractors.

The most contractors have a knowledge of the existences of PIAC, but they have not a clear knowledge about its website, its location, interaction between PIAC and Palestinian contractor union (PCU), list of qualified arbitrators of PIAC, its activities, employees and the headquarter of PIAC, and the minimal knowledge about the date of its establishment.

According to the analysis of a table 4 of questioner that discusses that role of PIAC in solving and eliminating the disputes between the contractor and owner, the analyses shows that the most activities of problems is based on the selection of the qualified arbitrators, beside respondent's contractor agreed that PIAC has a justified resolution and procedure in solving the disputes between contractor and the owners.

It is worthily to the mentioned due to analysis of the questioner that PIAC has a high transparency and solve the disputes in reasonable.

In table 5 that discusses the procedure and polices in solving disputes between contractor and owner, that is a high agreement from contractor's about PIAC, and the deeply trusted it. In addition, the contractors believe that the PIAC follows the legal procedure in solving the disputes. Besides, the contractors agree that the PIAC has an effective altitude in listening total parties of disputes and this result agree with the transparency of PIAC as the contractor voted by consensus.

Although the contractors believe that the time consumes in arbitration will be a reasonable time with respect to the time needed for the court. But at the same time, they believed that PIAC could need a long time to solve the disputes and this justified to the lack of capabilities and this due to the lack of financial supports

The contractors believed that the effectiveness of PIAC will encourage the investment in Palestine and this is an obvious conclusion because all parties will persuade and convinced that there is an efficient support to save their rights. But, this is related to an efficient and very strong PIAC. According to contractors, they believed in justice fees that PIAC will gain from solving disputes.

As concluded from the analysis of the difficulties that faced the PIAC, the main point that represents an obstacle is the absence of media activities for PIAC. This result matches with the agreement of contractors in table 7 which discusses the solutions for difficulties.

This table (table 7) shows that the highest activity could be provided by PIAC to be efficient is to take care with efficient media resources.

In table 6 as mentioned by contractors that the existence of PIAC centers in other main countries represents a high effect on the PIAC efficiency, the point reconciled with the mentioned of contractors in table 7 this point asses the existence of PIAC branches in the main cites in Palestine.

\section{DISCUSSION}

From the results in table two: Almost all contractors agree that the importance role of Palestinian International Arbitration Chamber (PIAC) summarized and represented in solving disputes between contractors and owners, and the main point resulted from the analysis of questionnaire is the policies rules and procedure of PIAC, this item is mentioned in the third part of questionnaire.

In general, there is a clear lack in the contractor's knowledge about Palestinian International arbitration chamber (PIAC), contractors believe in the necessity of the existence of PIAC to resolve disputes although the newly constructed chamber in addition to the lack of knowledge of the chamber between contractors. 
International Journal of Engineering Research and Technology. ISSN 0974-3154, Volume 13, Number 9 (2020), pp. 2444-2452

(C) International Research Publication House. https://dx.doi.org/10.37624/IJERT/13.9.2020.2444-2452

The most contractors have a knowledge of the existences of PIAC, but they have not a clear knowledge about its website, its location, interaction between PIAC and Palestinian contractor union (PCU), list of qualified arbitrators of PIAC, its activities, employees and the headquarter of PIAC, and the minimal knowledge about the date of its establishment.

According to the analysis of a table 4 of questioner that discusses that role of PIAC in solving and eliminating the disputes between the contractor and owner, the analyses shows that the most activities of problems is based on the selection of the qualified arbitrators, beside respondent's contractor agreed that PIAC has a justified resolution and procedure in solving the disputes between contractor and the owners.

It is worthily to the mentioned due to analysis of the questioner that PIAC has a high transparency and solve the disputes in reasonable.

In table 5 that discusses the procedure and polices in solving disputes between contractor and owner, that is a high agreement from contractor's about PIAC, and the deeply trusted it.

In addition, the contractors believe that the PIAC follows the legal procedure in solving the disputes.

Besides, the contractors agree that the PIAC has an effective altitude in listening total parties of disputes and this result agree with the transparency of PIAC as the contractor voted by consensus.

Although the contractors believe that the time consumes in arbitration will be a reasonable time with respect to the time needed for the court.

But at the same time, they believed that PIAC could need a long time to solve the disputes and this justified to the lack of capabilities and this due to the lack of financial supports

The contractors believed that the effectiveness of PIAC will encourage the investment in Palestine and this is an obvious conclusion because all parties will persuade and convinced that there is an efficient support to save their rights. But, this is related to an efficient and very strong PIAC. According to contractors, they believed in a justice fees that PIAC will gain from solving disputes.

As concluded from the analysis of the difficulties that faced the PIAC, the main point that represents an obstacle is the absence of media activities for PIAC. This result matches with the agreement of contractors in table 14 which discusses the solutions for difficulties.

This table (table 7) shows that the highest activity could be provided by PIAC to be efficient is to take care with efficient media resources.

In table 6 as mentioned by contractors that the existence of PIAC centers in other main countries represents a high effect on the PIAC efficiency, the point reconciled with the mentioned of contractors in table 14 this point asses the existence of PIAC branches in the main cites in Palestine.

The contractors have a high agreement on the followings that represents obstacles and difficulties that will face PIAC:

- The lacking media activates for identifying the chamber to both contractors and project owner.

- The chamber inability to establish additional centers in the various Palestinian cites.

- An available of adequate fund.

- A little coordinate between PIAC and the courts.

- Lack of contentment among the disputes parties about the chamber.

- Lack of suitable experience among the chamber qualified arbitrator.

\section{CONCLUSION}

Through what has been studied in this project around the Palestinian International Arbitration Chamber efficiency, the output results summarized as follows: -

Under the current situation PIAC able to do its job to resolve disputes between contractors and owners, for the following reasons:-

- The existence of arbitrators qualified to conduct an operation arbitration.

- The existence of chamber encouraging investment in Palestine.

- The existence of relative confidence of the contractors in chamber resort to resolve disputes that may occur between parties issues and this was confirmed by the results of questionnaire.

The presence of high secrecy in the PIAC where this feature adds character is superior to the court that exposes people. In table 7 the solutions suggested by contractor to have efficiency PIAC summarized by the followings:

- Provide an efficient media highlighted the role of PIAC.

- Provide a qualified arbitrator in solving disputes by several methods, such as seminars, courses, participation with other international chambers. In Gaza Strip, the disputes increase between all parties involved in construction industry, the final recommendation of the paper written by Enshassi et al [2] is to focus on organization of regular training programs. These organization aims to enrich the knowledge concerning dispute resolution system among all parties in construction industry [3]

- Provide awareness and brochures about the activities of chamber.

- Provide centers in most cities.

- Provide financial resources for PIAC.

- Provide coordinate with the court.

- It is advisable to have an "Arbitration agreement" in the contracts between the construction industry parties. As stated in the "Proposed Palestinian Law on International Commercial Arbitration", the arbitration agreement is an agreement by the parties at certain disputes that arise or may be arise between them, and 
an arbitration agreement may be in the form of arbitration clause in a contract or in a separate agreement [4].

Finally, there are a lot of plans that seek to develop the structure of PIAC, through chamber visit and meet the head and members of the chamber; it was founded that there is an ongoing planning process to develop the performance of chamber in order to increase the efficiency of chamber.

The Palestinian Chamber should pay more attention in etransaction contracts, since the disputes may arise; several companies or peoples purchased goods on the internet. The paper written by Yahya Hasan shows the essential of suitable resolution for a new environment of e-transaction [5].

In recent times, PIAC planned for the adoption of technology (video conference) where it's a good technique by which to call and deal with global arbitrators without resorting to travel, an international qualified cadre from a large number of disciplines was hired.

The lack of public and private Investment in Palestinian Authority region caused by many factors, among these is due to the lack of stable legal framework in West Bank and Gaza [6]. The existence of the arbitration chamber in Palestine gives good imparted to invest in Palestine and through its interaction with other institutions where the Palestinian chamber of arbitration contracted with several government ministries, and it encourages these ministries to expand their projects and investment due to the existence of an entity guarantees the right as soon as possible, in addition to that the presence of chamber gives the identity of Palestine in international forums.

\section{REFERENCES}

[1] Al Tamimi, Essam. 2009. "Practitioner's Guide to Arbitration in the Middle East and North Africa." (Juris Publishing, Inc).

[2] Enshassi, Adnan, \& Abu Rass, Ahmad. 2008. "Dispute resolution practice in the construction industry in Palestine." International Confrence on Multi-National Construction Project.

[3] Concil, Palestine Legislative. 2000. "Proposed Palestinian Law on International Commercial Arbitration."

[4] Hasan, Yahya. 2016. "Dispute Resolution in ETransaction in Palestine." (Islamic University Malaysia Sonny Zulhuda).

[5] Besaiso, Haytham, Fenn Peter and Emsly, Margaret. 2018. "Evolution of Construction Arbitration." Journal of Legal Affairs and Dispute Resolution in Engineering and Construction 10.

[6] Quast, Marshall J. Berger and Shelby. 2000. "International Commercial Arbitration." 